\title{
Kainate Receptors Mediate Synaptic Input to Transient and Sustained OFF Visual Pathways in Primate Retina
}

\author{
Theresa Puthussery, ${ }^{1}$ Kumiko A. Percival, ${ }^{1,2,3}$ Sowmya Venkataramani, ${ }^{1}$ Jacqueline Gayet-Primo, ${ }^{1}$ Ulrike Grünert, ${ }^{2,3}$ \\ and W. Rowland Taylor ${ }^{1}$ \\ ${ }^{1}$ Casey Eye Institute, Department of Ophthalmology, Oregon Health and Science University, Portland, Oregon 97239, ${ }^{2}$ Department of Ophthalmology, Save \\ Sight Institute, University of Sydney, Sydney, NSW 2000, Australia, and ${ }^{3}$ Australian Research Council Centre of Excellence in Vision Science, University of \\ Sydney, Sydney, NSW 2000, Australia
}

Visual signals are segregated into parallel pathways at the first synapse in the retina between cones and bipolar cells. Within the OFF pathways of mammals, the selective expression of AMPA or kainate-type glutamate receptors in the dendrites of different OFF-bipolar cell types is thought to contribute to formation of distinct temporal channels. AMPA receptors, with rapid recovery from desensitization, are proposed to transmit high temporal frequency signals, whereas kainate receptors (KARs) are presumed to encode lower temporal frequencies. Here we studied the glutamate receptors expressed by OFF-bipolar cells in slice preparations of macaque monkey retina, where the low (midget/parvocellular) and high-frequency (parasol/magnocellular) temporal channels are well characterized. We found that all OFF-bipolar types receive input primarily through KARs and that KAR antagonists block light-evoked input to both OFF-midget and OFF-parasol ganglion cells. KAR subunits were differentially expressed in OFF-bipolar types; the diffuse bipolar (DB) cells, DB2 and DB3b, expressed GluK1 and showed transient responses to glutamate and the KAR agonist, ATPA. In contrast, flat midget bipolar, DB1, and DB3a cells lacked GluK1 and showed relatively sustained responses. Finally, we found that the KAR accessory protein, Neto1, is expressed at the base of cone pedicles but is not colocalized with the GluK1 subunit. In summary, the results indicate that transient signaling in the OFF pathway of macaques is not dependent on AMPA receptors and that heterogeneity of KARs and accessory proteins may contribute to the formation of parallel temporal channels.

Key words: bipolar cells; ganglion cells; kainate receptors; Neto1; primate; retina

\section{Introduction}

In the mammalian visual system, parallel channels are established in the retina during signal transmission from photoreceptors, through bipolar cells, to ganglion cells. Functional properties of the parallel channels are specified by glutamate receptors at the synapse between photoreceptors and bipolar cells. For example, OFF-bipolar cells encode decrements in light intensity using ionotropic AMPA/kainate type receptors (Slaughter and Miller, 1983), whereas ON-bipolar cells encode increments in light intensity using metabotropic glutamate receptors (mGluR6) (Slaughter and Miller, 1981; Nomura et al., 1994; Masu et al., 1995).

\footnotetext{
Received Nov. 18, 2013; revised March 27, 2014; accepted April 25, 2014

Author contributions: T.P. and W.R.T. designed research; T.P., K.A.P., S.V., and J.G.-P. performed research; T.P., K.A.P., S.V., and W.R.T. analyzed data; T.P., U.G., and W.R.T. wrote the paper.

This work was supported by EY014888 to W.R.T., a Collins Medical Trust Grant to T.P., a Lew R. Wasserman Award from Research to Prevent Blindness to W.R.T., and the Ophthalmology (P30-EY010572) and Advanced Light Microscopy Core Facilities at Oregon Health and Science University (P30NS061800-04). We thank Drs. Paul Martin and llya Buldyrev for helpful comments on the manuscript; and Dr. Stefanie Kaech-Petrie and Aurelie Snyder for assistance with SR-SIM imaging.

The authors declare no competing financial interests.

Correspondence should be addressed to Dr. Theresa Puthussery, Casey Eye Institute, Department of Ophthalmology, Oregon Health and Science University, 3375 SW Terwilliger Blvd, Portland, OR 97239. E-mail: puthusse@ohsu.edu.

DOI:10.1523/JNEUROSCI.4855-13.2014

Copyright $\odot 2014$ the authors $\quad 0270-6474 / 14 / 347611-11 \$ 15.00 / 0$
}

Within the OFF channel, further functional diversity is introduced by heterogeneity within glutamate receptor subclasses. In ground squirrel and mouse retina, OFF-bipolar cell currents are dominated by either AMPA or kainate receptor (KAR) currents, and this distinction is thought to be important for temporal filtering of cone signals (DeVries, 2000; DeVries et al., 2006; Puller et al., 2007). Cell types that express AMPA receptors (AMPARs), which recover more rapidly from desensitization, are presumed to encode higher temporal frequencies than those expressing KARs, which recover relatively slowly (DeVries, 2000). This principle predicts that bipolar cells expressing AMPARs drive transient (higher temporal frequency) visual channels, whereas those expressing KARs drive sustained (lower temporal frequency) channels. However, this hypothesis has not yet been examined because, in most mammals, the ganglion cell targets of the various OFF-bipolar cell types have not been determined. A central goal of this study was to exploit the well-characterized circuits of the primate OFF-parvocellular (sustained) and OFFmagnocellular (transient) channels, to directly test the hypothesis that AMPAR-expressing bipolar cells contribute to temporal tuning in transient retinal pathways.

In addition to the AMPA/kainate dichotomy, previous studies point to pharmacological heterogeneity in KARs across OFFbipolar cell types (DeVries and Schwartz, 1999; DeVries, 2000; Lindstrom et al., 2014). However, the molecular basis and func- 
tional implications of this diversity remain unclear. KARs are tetramers formed from combinations of five receptor subunits, GluK1-5 (Hollmann and Heinemann, 1994). The low-affinity subunits, GluK1-3, can form functional homomers, whereas the high-affinity subunits, GluK4 and GluK5, must partner with a low-affinity subunit to form functional channels (Ren et al., 2003; Nasu-Nishimura et al., 2006). Although variations in subunit composition can confer different functional properties to synaptic KARs, recent evidence indicates that interaction with the auxillary proteins, Neto 1 and Neto2, can also markedly alter kinetic properties (Tomita and Castillo, 2012; for reviews, see Copits and Swanson, 2012). The retina is an ideal model system to study KAR heterogeneity because the synapses between cone pedicles and OFF-bipolar cells represent a rare example of central synapses in which EPSCs are mediated primarily by KARs. Here, we have used electrophysiological and immunohistochemical methods to investigate the functional diversity of KARs expressed by primate OFF-bipolar cells.

\section{Materials and Methods}

Animal procedures and tissue preparation. Eyes were obtained from 24 rhesus (Macaca mulatta) and 9 cynomolgous (Macaca fascicularis) macaques of either sex that were killed for unrelated experiments according to procedures of the Tissue Distribution Program at the Oregon National Primate Research Center. After exsanguination, eyes were enucleated, the anterior eye and vitreous were removed, and the retina-RPE-choroid complex was isolated from the sclera in bicarbonate-buffered Ames' medium (US Biologicals) equilibrated with carbogen $\left(95 \% \mathrm{O}_{2} / 5 \% \mathrm{CO}_{2}\right)$. All subsequent slice procedures and bipolar and ganglion cell recordings were performed in Ames' medium. For slice recordings, pieces of lightadapted peripheral retina (eccentricity $\sim 4-8 \mathrm{~mm}$ ) were embedded in $3 \%$ low melting temperature agarose in HEPES-buffered Ames' and vertical slices $(\sim 300 \mu \mathrm{m})$ were cut on a vibrating microtome (Leica Biosystems).

Bipolar and horizontal cell recordings. Slices were visualized with gradient contrast optics on an Olympus BX-51 WI microscope using infrared illumination $(870 \mathrm{~nm})$. Slices were continuously superfused (2-3 $\mathrm{ml} / \mathrm{min}$ ) in Ames' medium heated to $31 \mathrm{C}-33^{\circ} \mathrm{C}$. Borosilicate pipettes $(9-12 \mathrm{M} \Omega)$ were wrapped in Parafilm to reduce pipette capacitance and were filled with an intracellular solution containing the following (in $\mathrm{mM}$ ): $120 \mathrm{~K}$-methylsulfonate, $8 \mathrm{KCl}, 2 \mathrm{Mg}_{2}$-ATP, $1 \mathrm{Na}$-GTP, 1 EGTA, 10 $\mathrm{Na}_{0.5}$-HEPES, 10 phosphocreatine- $\mathrm{Na}_{2}$, and 0.1 AlexaFluor-488 hydrazide (adjusted to pH 7.35 with $\mathrm{KOH}$ ). The liquid junction potential correction for this solution was $-10 \mathrm{mV}$. After establishing the wholecell recording configuration, a series of depolarizing or hyperpolarizing voltage steps were made from a holding potential of $-70 \mathrm{mV}$ to determine the inventory of voltage-gated currents in each cell. This was used, in addition to cell morphology, as a way of distinguishing between the different OFF cone bipolar cell types, as has been described previously (Puthussery et al., 2013). To isolate excitatory currents, all agonistevoked currents in bipolar and horizontal cells were measured at a holding potential of $-70 \mathrm{mV}$, the calculated chloride equilibrium potential. For focal drug application, a 9-12 $\mathrm{M} \Omega$ pipette was attached to a Picospritzer, and puffs were delivered at 3-5 psi. Puff-applied drugs L-glutamate (Sigma) and ATPA (Tocris Bioscience) were diluted in HEPES-buffered Ames' medium ( $\mathrm{pH}$ at 7.4). To assess the effect of glutamate receptor antagonists, $20 \mathrm{~ms}$ puffs of $0.5 \mathrm{~mm}$ glutamate were repeated every $10 \mathrm{~s}$. Once a stable baseline was established, the perfusion was switched to wash-in antagonists (ACET, UBP310 and GYKI53655, all from Abcam). Five to 8 traces were averaged before, during, and after drug application to calculate percentage suppression.

Currents were filtered at a $-3 \mathrm{~dB}$ cutoff frequency of $2 \mathrm{kHz}$ by the 4 pole Bessel filter of EPC-10 patch amplifier (HEKA), and digitized at 10 $\mathrm{kHz}$. Series resistance was not compensated online, but was monitored continuously during experiments by applying $5 \mathrm{mV}$ voltage steps. Series resistances were compensated offline by adjusting the amplitude of the current responses to account for changes in the driving force. For paired recordings, cones were patched at the inner segment with a recording electrode (7-8 $\mathrm{M} \Omega$ ) containing in mM: $120 \mathrm{Cs}$-methylsulfonate, $8 \mathrm{CsCl}, 2$ $\mathrm{Mg}_{2}$-ATP, 1 Na-GTP, 1 EGTA, $10 \mathrm{Na}_{0.5}$-HEPES, $10 \mathrm{Na}_{2}$-phosphocreatine, and 0.1 AlexaFluor- 488 or -594 hydrazide (adjusted to $\mathrm{pH}$ 7.35 with $\mathrm{CsOH})$.

Ganglion cell recordings. Ganglion cell recordings were made in wholemount preparations of peripheral nasal retina (eccentricity 5-10 mm) with the RPE/choroid attached. The retina was continuously superfused in Ames' medium $\left(35^{\circ} \mathrm{C}\right)$ at a rate of $2-4 \mathrm{ml} / \mathrm{min}$. The preparation was visualized with differential interference or gradient contrast optics using infra-red illumination $(870 \mathrm{~nm})$. Midget and parasol ganglion cells were initially targeted based on soma size and physiologically identified by assessing receptive field size, contrast sensitivity, and temporal response properties during light stimulation in the loose-cell attached recording configuration (De Monasterio and Gouras, 1975; Watanabe and Rodieck, 1989; Crook et al., 2008). Loose-patch recordings were made with $\sim 5 \mathrm{~m} \Omega$ pipettes filled with Ames' medium. Voltage-clamp recordings were subsequently made with $\sim 5 \mathrm{M} \Omega$ pipettes containing in mM: 128 Cs-methylsulfonate, $6 \mathrm{CsCl}, 2 \mathrm{Mg}$-ATP, $1 \mathrm{Na}-\mathrm{GTP}, 1$ EGTA, $10 \mathrm{Na}_{0.5^{-}}$ HEPES, $2.5 \mathrm{Na}_{2}$-phosphocreatine, and 3 QX-314 and 0.5 Alexa-594 hydrazide. The liquid junction potential correction for this solution was $-16 \mathrm{mV}$. The identity of recorded cells was confirmed by assessing morphology at the conclusion of the recordings (Watanabe and Rodieck, 1989). Currents were filtered and digitized as for bipolar cells. Light stimuli were delivered with a CRT monitor (peak $\lambda=540 \mathrm{~nm}$ ) or OLED display (Emagin microdisplay; peak $\lambda=518 \mathrm{~nm}$ ) projected onto the preparation through the microscope objective $(10 \times$ or $20 \times)$. Percentage contrast, defined as $100 \times\left(\mathrm{L}_{\max }-\mathrm{L}_{\text {min }}\right) / \mathrm{L}_{\text {background }}$, was set to $50 \%$ (whole-cell recordings) or 100\% (spike recordings). Background intensities were rod-saturating, ranging from $\sim 1.9 \times 10^{3}$ to $\sim 1.5 \times 10^{5}$ photons $\cdot \mathrm{s}^{-1} \cdot \mu \mathrm{m}^{2}$.

The effect of antagonists on ganglion cell spiking was assessed by measuring the mean firing rate over the first $50 \mathrm{~ms}$ of the second stimulus cycle. The synaptic conductance elicited by light stimulation was estimated by obtaining light responses at six holding potentials, from -116 to $44 \mathrm{mV}$ in $20 \mathrm{mV}$ increments as described previously (Venkataramani and Taylor, 2010; Buldyrev et al., 2012). Current-voltage (I-V) relations of the net light-evoked currents were measured at $10 \mathrm{~ms}$ intervals and were fit to the equation:

$$
I=G_{i n h i b}\left(V-E_{C l}\right)+\left(G_{A M P A}+G_{N M D A} /\left(1+e^{-\left(V-V_{0.5}\right) / V_{\delta}}\right)\right)\left(V-V_{e}\right)
$$

where $V$ is the membrane potential, $G_{i n h i b}$ is the inhibitory conductance, $G_{A M P A}$ is the linear component of the excitatory conductance, $G_{N M D A}$ is a nonlinear conductance with a voltage-dependent I-V relation appropriate for NMDA channel activation, $E_{C l}$ is the chloride equilibrium potential $(-70 \mathrm{mV})$, and $V_{e}$ is the excitatory reversal potential $(0 \mathrm{mV})$. $E_{C l}$ and $V_{e}$ were fixed, whereas $G_{i n h i b}, G_{A M P A}$, and $G_{N M D A}$ were allowed to vary during fitting. $V_{0.5}$ is the potential at which half the NMDA channels are blocked by extracellular Mg ions, and $V_{\delta}$ sets the voltage sensitivity of the block. $V_{0.5}$ and $V_{\delta}$ were fixed at -30 and $18 \mathrm{mV}$, respectively. Although these parameter values produced adequate fits to the I-V relations of the OFF midget ganglion cells, the precise values are not critical for the present purposes because the goal was simply to determine whether synaptic inputs were suppressed by KAR antagonists. The I-V relations for OFF parasol ganglion cells were fit using only linear conductances by fixing $G_{N M D A}=0$. Analysis was performed using custom routines in Igor Pro (Wavemetrics).

Immunohistochemistry and imaging. The following primary antibodies and tissue culture supernatants were used; rabbit anti-recoverin (Millipore, \#AB5585), rabbit or sheep anti-secretagogin (Biovendor R\&D, \#RD181120100, RD184120100), rabbit anti-glutamate transporter 1 (GLT-1, Tocris Bioscience, \#2063), mouse anti-calbindin D28K (Sigma, \#C9848), mouse anti-Islet-1 (Developmental Hybridoma Studies Bank, University of Iowa, \#39.4D5), rabbit anti-calcium binding protein 5 (CaBP5, gift from Dr. F. Haeseleer), goat anti-GluK1 antibody (GluR5, Santa Cruz Biotechnology, SC-7616), goat anti-GluA3 (GluR3, Santa Cruz Biotechnology, sc-7612), rabbit anti-GluA4 (GluR4, Millipore, \#AB1508), rabbit anti-neuropilin and tolloid-like 1 (Neto1, kindly provided by Dr Masahiko Watanabe, Hokkaido University (Straub et al., 
2011), mouse anti-RIBEYE (CtBP2, BD Biosciences, \#612044), and mouse anti-PSD-95 (University of California at Davis/National Institutes of Health Neuromab \#73-348, clone K28/74).

For immunostaining, retinae were fixed for $5 \mathrm{~min}$ in 2 or $4 \%$ PFA at $25^{\circ} \mathrm{C}$, cryoprotected in graded sucrose solutions and cryosectioned at 12 $\mu \mathrm{m}$. Nonspecific binding sites were blocked for $3 \mathrm{~h}$ with $10 \%$ normal horse serum (NHS), 1\% Triton X-100, 0.025\% $\mathrm{NaN}_{3}$ in PBS, pH 7.4, and primary antibodies were applied in 3\% NHS, 1\% Triton X-100, 0.025\% $\mathrm{NaN}_{3}$ in PBS, pH 7.4 overnight at $25^{\circ} \mathrm{C}$. Immunostaining shown in Figure 6 was performed sequentially, with GluK1 detected first, followed by cell marker antibodies. Secondary antibodies, raised in donkey, were conjugated to AlexaFluor-488, -594, or -647 (Invitrogen). These were diluted in $3 \%$ NHS, $0.025 \% \mathrm{NaN}_{3}$ in PBS, pH 7.4, and applied for $1 \mathrm{~h}$ at $25^{\circ} \mathrm{C}$. The following modifications were made for sample preparation for super-resolution structured illumination microscopy (SR-SIM): retinae were postfixed in 4\% PFA for $30 \mathrm{~min}$ after application of secondary antibodies and tissues were mounted using CFM-1 mounting medium (Citifluor, refractive index 1.51). For SR-SIM, only AlexaFluor-488 and -594-conjugated secondary antibodies were used.

In some cases, at the conclusion of recordings, agarose slices were fixed for 15-30 min in 4\% PFA for subsequent confocal imaging. All confocal images were acquired on an Olympus Fluoview 1000 confocal microscope with an Olympus Plan Apo $60 \times$ (1.42 NA oil) objective. Linear image adjustments (brightness and contrast) were applied uniformly using Adobe Photoshop CS. The confocal images shown are maximal $z$-projections of 2-4 image planes, whereas all SR-SIM images are of single optical sections unless otherwise indicated.

Structured illumination microscopy and image analysis. For SR-SIM, images were acquired with an Elyra PS.1 Microscope (Carl Zeiss) with a $60 \times / 1.4$ (NA) PlanApo objective using an Andor iXON EMCCD camera, and processed for SR-SIM using ZEN 2010D software. Images were corrected for chromatic aberration by applying a correction obtained from alignment of SIM images of $0.1 \mu \mathrm{m}$ TetraSpeck Microspheres (Invitrogen).

To determine the extent of overlap between Neto1 and GluK1 immunolabeling, SIM image stacks from retinal whole mounts and vertical sections were analyzed in 3D using IMARIS software (Bitplane). Images were background subtracted and filtered using a mean intensity threshold to reduce noise. The "Spots" tool was then used to fit ellipses $(0.25 \times$ $0.75 \mu \mathrm{m}$ width by height) to immunoreactive puncta in each color channel, and the extent of overlap between Netol and GluK1 puncta was determined by finding Netol and GluK1 puncta with centers separated by $\leq 0.12 \mu \mathrm{m}$, the approximate resolution limit that can be achieved using SIM. As a positive control, we applied similar analyses to images of $0.1 \mu \mathrm{m}$ TetraSpeck Microspheres (Invitrogen), which showed 100\% colocalization at a spatial threshold of $0.12 \mu \mathrm{m}$. Analysis of the AMPAR subunits, GluA3 and GluA4, also showed a high degree of colocalization (58\% of GluA3 puncta colocalized with GluA4, $n=5836$ total GluA4 puncta, $n=5799$ total GluA3 puncta) at a spatial threshold of $0.12 \mu \mathrm{m}$ (Abbott et al., 2012). To ensure that the resolution of our approach was adequate to resolve presynaptic and postsynaptic synaptic markers, we analyzed retinal sections labeled for CtBP2/RIBEYE (a marker of presynaptic ribbon synapses) and GluA4 (a marker of AMPA postsynapses). We found that, as expected, these proteins showed little spatial overlap $(3.7 \%$ of GluR4 puncta colocalized with RIBEYE, $n=1152$ total puncta for RIBEYE, $n=1082$ total puncta for GluA4) at a spatial threshold of $0.12 \mu \mathrm{m}$.

Statistics. Statistical comparisons of antagonist effects on glutamateevoked currents were made for bipolar cells using two-way ANOVA ("cell type" $\times$ "drug") and for horizontal cells using one-way ANOVA. Bonferroni post hoc tests were used in both cases. Wilcoxon Rank-Sum test was used for comparisons of nonparametric datasets where indicated. Statistics were calculated with GraphPad Prism 4.0a or Igor Pro 6.34 .

\section{Results}

Over the course of this study, we recorded from all five OFFbipolar cell types that have been identified in macaque retina
(Boycott and Wässle, 1991; Haverkamp et al., 2003; Puthussery et al., 2013); the flat midget bipolar cell (FMB, $n=37)$ and four diffuse bipolar (DB) cell types: DB1 $(n=14)$, DB2 $(n=26)$, DB3a $(n=13)$, and DB3b $(n=22)$. FMB cells drive OFF-midget ganglion cells (Kolb and Dekorver, 1991; Calkins et al., 1994), whereas the diffuse bipolar cell types, DB2, DB3a, and possibly DB3b cells drive OFF-parasol ganglion cells (Jacoby et al., 2000; Calkins and Sterling, 2007; Puthussery et al., 2013). The different OFF-bipolar cell types were discriminated by examining their inventory of voltage-gated currents (Puthussery et al., 2013) (see Materials and Methods) and by assessing cell morphology (Boycott and Wässle, 1991; Puthussery et al., 2013) at the conclusion of the recordings.

\section{Glutamate activates KARs in OFF cone bipolar cells}

Our first objective was to characterize the pharmacology of glutamate-evoked currents in each OFF-bipolar cell type. Focal dendritic application of L-glutamate $(0.5 \mathrm{~mm}, 0.5 \mathrm{~s})$ produced inward currents in all OFF-bipolar cells; however, the response kinetics varied between bipolar types (Fig. 1A). The FMB, DB1, and DB3a cells showed relatively sustained responses to $0.5 \mathrm{~s}$ L-glutamate puffs, with the following plateau/peak amplitude ratios (mean \pm SD): FMB, $0.64 \pm 0.15(n=11)$; DB1, $0.95 \pm 0.07$ $(n=5)$; and DB3a, $0.79 \pm 0.17(n=2)$. DB2 and DB3b cells showed more transient responses with plateau/peak amplitude ratios: DB2, $0.22 \pm 0.03(n=6)$ and DB3b $0.36 \pm 0.17(n=7)$. The plateau/peak ratios of DB2 and DB3b cells were significantly smaller than that of FMB cells (Wilcoxon Rank Test, FMB vs $\mathrm{DB} 2, p=0.0002$; FMB vs DB3b, $p=0.0017)$, suggesting more pronounced desensitization in the DB2 and DB3b cells.

To determine whether the observed differences in response kinetics could be attributed to differential expression of AMPA versus KARs, we measured the sensitivity of glutamate-evoked currents to the noncompetitive AMPAR antagonist, GYKI 53655 (Wilding and Huettner, 1995; Bleakman et al., 1996) or the competitive KAR antagonist, ACET (also known as UBP316, 0.1-1 $\mu \mathrm{M}$ (Dolman et al., 2007; Dargan et al., 2009; Perrais et al., 2009). A concentration of $10 \mu \mathrm{M}$ GYKI 53655 was selected to maximize block of AMPA receptors $\left(\mathrm{IC}_{50} \sim 2 \mu \mathrm{M}\right.$ ) while minimizing effects at GluK3 or GluK2/3 containing KARs ( $\mathrm{IC}_{50} \sim 32-63 \mu \mathrm{M}$ ) (Perrais et al., 2009). The peak glutamate-evoked currents were monitored during application of the antagonists (Fig. $1 B$ ). In the DB2 cell example shown in Figure 1B, GYKI 53655 had little effect on response amplitude, $0.1 \mu \mathrm{M}$ ACET produced substantial but incomplete block, whereas $1 \mu \mathrm{M}$ ACET abolished the L-glutamate response. In most instances, the recording duration did not permit sequential wash-in of antagonists, and thus only one of either GYKI 53655 or ACET was applied to an individual cell. We found that ACET suppressed glutamate-evoked currents by $>90 \%$ in all OFF-bipolar cell types (Fig. $1 C, D$ ). FMB, DB1, and DB3a cells were more sensitive to ACET ( 90\% block with $0.1 \mu \mathrm{M}$ ) than were DB2 and DB3b cells ( $\sim 90 \%$ block with $1.0 \mu \mathrm{M}$, Fig. $1 D$ ). Partial drug washout was generally observed within the available recording time (Fig. 1C). We also tested another competitive KAR antagonist, UBP310 (Dargan et al., 2009; Perrais et al., 2009), which produced similar results to ACET (tested in FMB and DB2 cells, Fig. 1D). In contrast to the KAR antagonists, the AMPAR antagonist, GYKI 53655, had modest effects, with maximal peak glutamate current suppression of $22.2 \%$ in FMB cells (Fig. 1D). Given that KAR antagonists suppressed FMB responses by $\sim 96 \%$ on average (Fig. 1D), it seems likely that the suppression by GYKI 53655 reflects its additional antagonistic activity at GluK2/3 or 
A

FMB
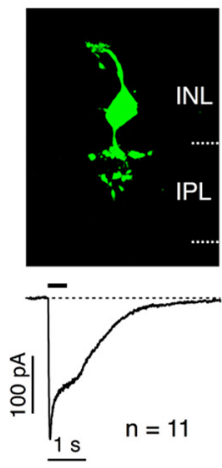

Control ACET Washout

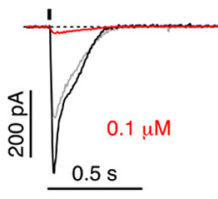

DB1
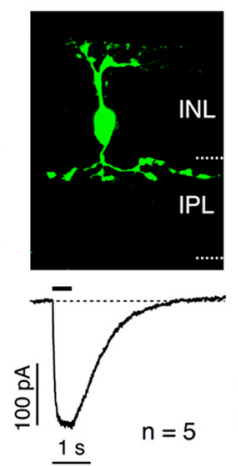

DB2
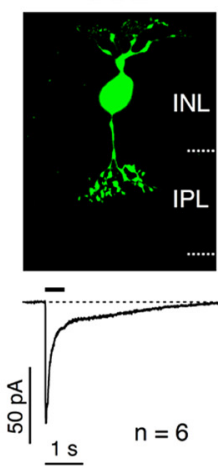

DB3a
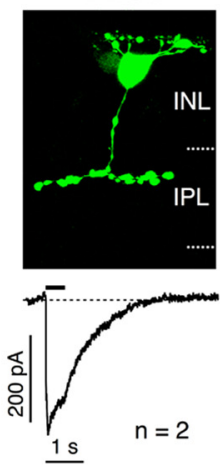

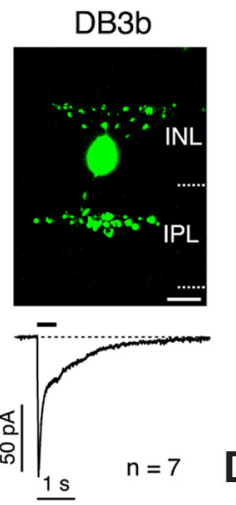

B L-Glu puffs, $0.5 \mathrm{mM}$

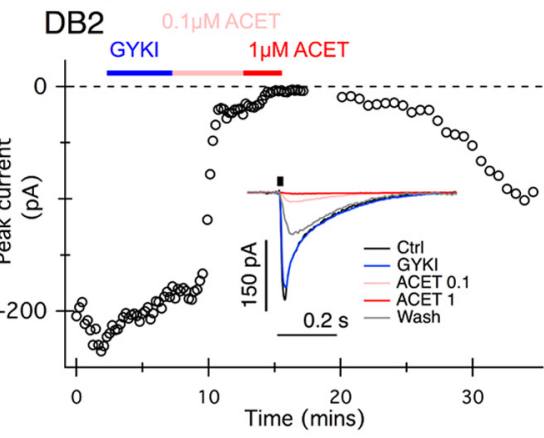

D

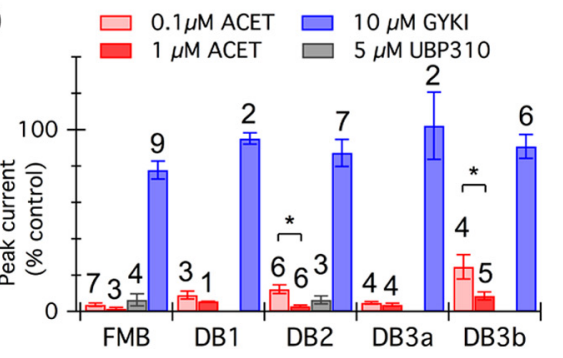

Figure 1. Macaque OFF cone bipolar cells express KARs. $\boldsymbol{A}$, Top, Confocal projections showing examples of each type of macaque $0 \mathrm{FF}-$ bipolar cell filled with Alexa-488 hydrazide during recordings. INL, Inner nuclear layer; IPL, inner plexiform layer. Scale bar, $10 \mu \mathrm{m}$. Scale bar, $10 \mu \mathrm{m}$. A, Bottom, Average currents in response to puff application of glutamate (L-Glu) to the OFF-bipolar cell dendrites $(0.5 \mathrm{~s}, 0.5 \mathrm{~mm})$. The number of cells averaged for each cell type is indicated. The black bar above the traces delineates the interval of glutamate application. Note the more transient response kinetics in DB2 and DB3b cells. $B$, An example recording from a DB2 cell showing the peak amplitude of currents evoked by $20 \mathrm{~ms}$ puffs of $0.5 \mathrm{~mm}$ glutamate at $15 \mathrm{~s}$ intervals. The bars above the data points indicate the timing of antagonist application. Inset, Average current responses obtained under the different drug conditions. C, Examples of glutamate-evoked currents ( $20 \mathrm{~ms}, 0.5 \mathrm{~mm}$ ) in each bipolar cell type (ordered left to right as in $A$ ), before, during, and after partial washout of ACET. Puff timing is indicated by the black bars above traces. $D$, Summary graph showing antagonist effects on peak currents for each cell type. The number of cells for each condition is indicated above the error bars. Note that DB2 and DB3b cells were relatively less sensitive to ACET. * $p<0.05$ (two-tailed Wilcoxon Rank Sum test). The effect of ACET ( 0.1 and $1 \mu \mathrm{M}$ ) was significantly different from the effect of GYKI 53655 for all cell types ( $p<0.001$, two-way ANOVA with Bonferroni tests). Error bars indicate \pm 1 SEM.
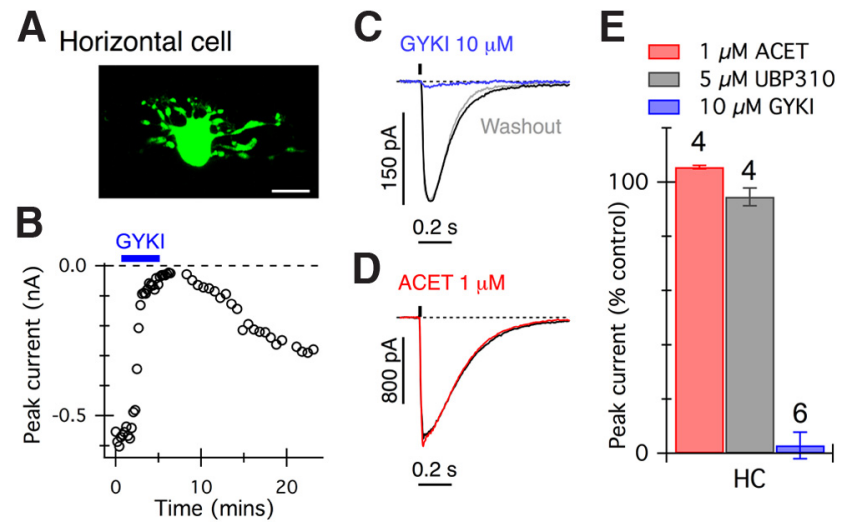

Figure 2. Glutamate-evoked currents in horizontal cells are blocked by AMPAR but not KAR antagonists. $\boldsymbol{A}$, Confocal projection showing an example of a recorded horizontal cell. Scale bar, $10 \mu \mathrm{m}$. $\boldsymbol{B}$, Graph showing peak glutamate-evoked ( $20 \mathrm{~ms}, 0.5 \mathrm{~mm}$ ) current amplitude in a horizontal cell. Application of GYKI 53655 (10 $\mu \mathrm{m}$, blue bar) strongly suppressed currents. $\boldsymbol{C}, \boldsymbol{D}$, Glutamate-evoked currents in two representative horizontal cells were reversibly blocked by $10 \mu \mathrm{m}$ GYKI 53655 (C) but not ACET (D).E, Summary of antagonist effects on glutamate-evoked currents in horizontal cells. The effect of ACET or UBP310 was significantly different from the effect of GYKI 53655 ( $p<0.001$, one-way ANOVA with Bonferroni post-tests). The number of cells tested in each group is indicated above bars.

GluK3 containing KARs, which is consistent with the immunohistochemical results shown below.

To confirm the efficacy and selectivity of the glutamate receptor antagonists in our preparation, we tested these drugs on glutamate-evoked currents in horizontal cells (Fig. 2A), which are known to receive synaptic input through AMPARs (Blanco and de la Villa, 1999; Diamond, 2011; Jackman et al., 2011). As expected, horizontal cell currents were rapidly blocked by $10 \mu \mathrm{M}$ GYKI 53655 (Fig. 2B,C,E), but not by high concentrations of ACET ( $1 \mu \mathrm{M}$, Fig. $2 D, E)$ or UBP310 ( $5 \mu \mathrm{M}$, Fig. $2 E)$. Analysis of the charge transfer during glutamate-evoked responses in both the bipolar cells and horizontal cells produced quantitatively similar results to measurements of peak current (data not shown). Together, these results indicate that glutamate-evoked responses in the five known primate OFF cone bipolar cell types are mediated predominantly by KARs.

\section{Flat midget bipolar cells express synaptic KARs}

We next sought to determine whether the antagonist sensitivity of glutamate-evoked responses reflected the pharmacology of synaptic receptors. We made paired, whole-cell recordings between cones and FMB cells and examined the sensitivity of evoked EPSCs to the glutamate receptor antagonists. We found that $0.1 \mu \mathrm{M}$ ACET blocked EPSCs elicited by direct depolarization of a presynaptic cone (Fig. $3 A, C$ ). The selectivity of the antagonists for synaptically evoked currents was further confirmed by paired recordings between cones and horizontal cells, which showed that EPSCs in horizontal cells were not blocked by $0.1 \mu \mathrm{M}$ ACET (Fig. $3 B, C$, red) but were blocked by $10 \mu \mathrm{M}$ GYKI 53655 (Fig. $3 B, C$, blue). Together, these data indicate that functional inputs to FMB cells are driven by KARs, and demonstrate that the pharmacology of glutamate-evoked currents is consistent with that of synaptic currents.

\section{KAR antagonists block light-evoked inputs to OFF-midget and OFF-parasol ganglion cells}

The results presented thus far indicate that cone to OFF-bipolar cell transmission is mediated predominantly by KARs, and there 

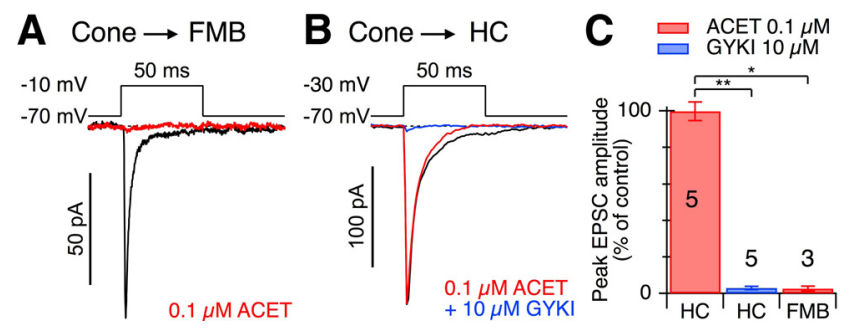

Figure 3. Cone to FMB EPSCs are mediated by KARs. $A$, Paired recording between a cone and an FMB cell. The cone voltage-step timing and magnitude are indicated above traces. The traces under each condition represent averages of 13 stimuli. Application of $0.1 \mu \mathrm{m}$ ACET suppressed the peak amplitude of the evoked EPSC by $\sim 97 \%$. B, Paired recording between a cone and a horizontal cell (HC) provides a positive control. The cone voltage-step timing and magnitude are indicated above the EPSCS. The traces for each condition represent averages of 8-10 stimuli. Application of $0.1 \mu \mathrm{M}$ ACET had little effect on the peak amplitude of the HC EPSC, whereas subsequent addition of $10 \mu \mathrm{m}$ GYKI 53655 suppressed the peak amplitude of the evoked EPSC by $\sim 98 \%$. C, Bar graph showing the effects of ACET and GYKI on average peak EPSC amplitudes during paired recordings between cones and the cell type indicated. The numbers of cell pairs averaged for each condition are indicated on the bars. Error bars indicate \pm 1 SEM. ${ }^{*} p<0.05$ (two-tailed Wilcoxon Rank Sum test). ${ }^{* *} p<0.01$ (two-tailed Wilcoxon Rank Sum test).

is no significant involvement of AMPA receptors. If KARs mediate synaptic input from cones to OFF cone bipolar cells, then OFF-pathway driven light-evoked inputs to OFF ganglion cells should be blocked by ACET. In contrast, ACET should not alter mGluR6-mediated transmission between cones and ON-bipolar cells. Immunohistochemical and electrophysiological studies indicate that KARs are not involved in signaling at bipolar to ganglion cell synapses (Jacoby and Wu, 2001; Grünert et al., 2002; Buldyrev et al., 2012); thus, ACET should not affect transmission at these inner retinal synapses. To test these predictions, we made loose cell-attached recordings from ganglion cells in retinal whole-mount preparations and recorded light-evoked spikes in response to a square-wave modulated $(1 \mathrm{~Hz}, 100 \%$ contrast $)$ spot stimulus centered on the receptive field. We found that ACET ( 1 $\mu \mathrm{M})$ reversibly blocked light-evoked spiking in OFF-midget and OFF-parasol ganglion cells (Fig. $4 A, B$ ) but had no effect on spiking in the corresponding ON ganglion cell types (Fig. 4C,D; peak spike rate \pm SEM percentage control, OFF midget $0 \pm 0 \%, n=5$ cells, ON midget $93 \pm 9 \%, n=3$ cells; OFF parasol $7 \pm 4 \%, n=$ 5 cells, ON parasol $118 \pm 7 \%, n=5$ cells, Wilcoxon rank sum test, $p=0.008)$. The maintained spiking in the OFF midget ganglion cells under background illumination was also suppressed by ACET, consistent with the suppression of a tonic input from FMB cells. In ON-OFF type ganglion cells, ACET reversibly blocked spikes evoked at the OFF-phase, but not the ON-phase of the light stimulus (Fig. $4 E ; n=2$ cells).

The effects of ACET on OFF ganglion cells are presumed to arise from blockade of OFF-bipolar cell excitatory inputs. However, spike recordings do not allow us to exclude the possibility that ACET suppressed spiking by increasing inhibitory input to the OFF-ganglion cells. Thus, we made voltage-clamp recordings from OFF ganglion cells to examine the effects of ACET on the light-evoked excitatory and inhibitory synaptic conductances (see Materials and Methods). For the OFF-midget ganglion cells, the excitatory conductances were well fit with a linear AMPAcomponent and a nonlinear NMDA component (Fig. $4 F$ ), as has been described previously (Crook et al., 2011). Excitatory conductances in OFF parasol ganglion cells were adequately fit with a linear AMPA conductance (Fig. 4G) (Puthussery et al., 2013). In both OFF-midget ( $n=4$ cells) and OFF-parasol ganglion cells ( $n=4$ cells), ACET blocked the excitatory synaptic conductances

\section{Control ACET Wash}
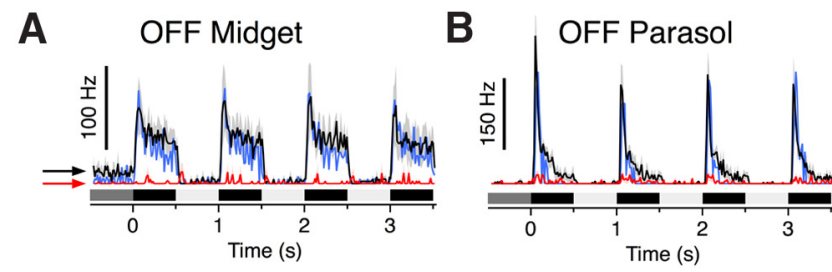

C ON Midget D ON Parasol E ON-OFF GC
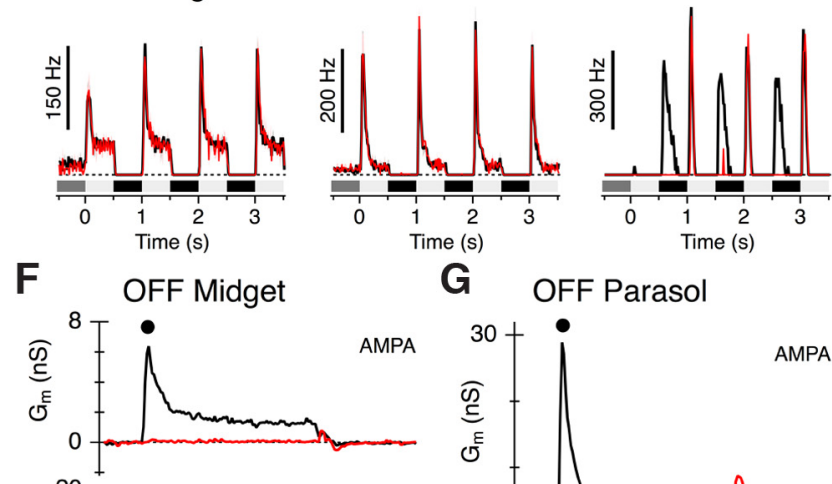

G OFF Parasol
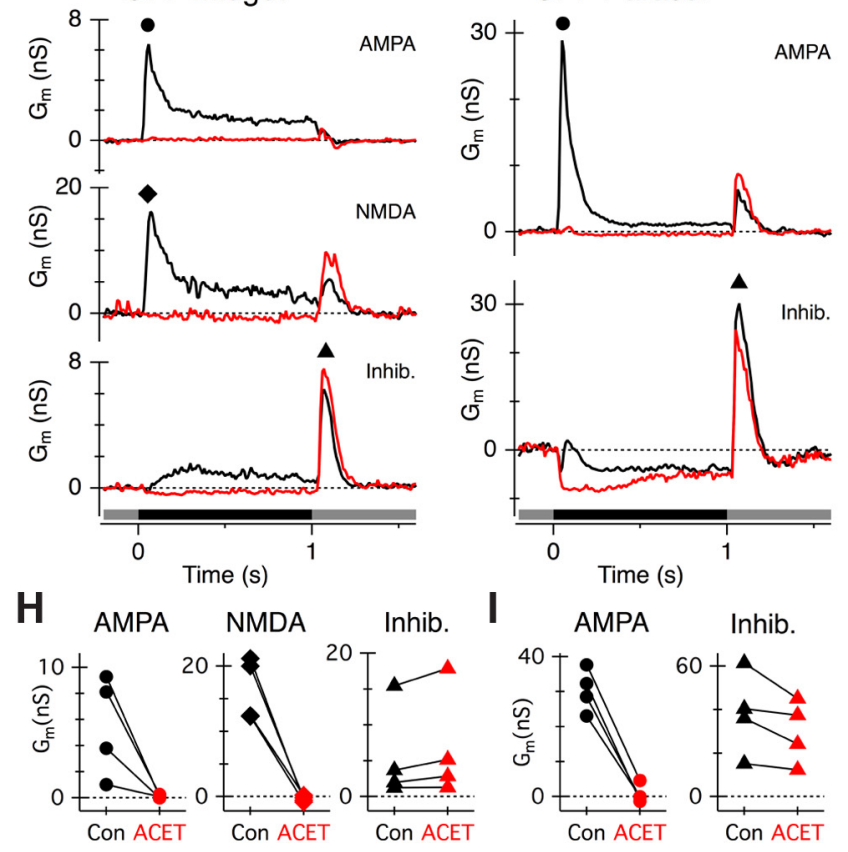

Figure 4. ACET suppresses light-evoked excitatory input to OFF-midget and OFF-parasol ganglion cells. Light stimulus timing and contrast is shown below traces for $\boldsymbol{A}-\mathbf{G}$. A-D, Average peristimulus spike-time histograms in OFF midget $(n=5)$, OFF parasol $(n=5)$, ON midget $(n=3)$, and ON parasol $(n=5)$ ganglion cells in control conditions (black traces) and during application of $1 \mu \mathrm{M}$ ACET (red traces). ACET suppressed spiking in OFF-type, but not ON-type, ganglion cells. Note that the background spiking in OFF midget cells was blocked by ACET (arrows), but not in ON midget cells. Washout responses (blue traces) are averages obtained from 4 OFF parasol and 2 OFF midget ganglion cells. $E$, Example peristimulus spike-time histogram of an ON-OFF ganglion cell under control conditions (black traces) and in ACET (red traces), showing selective block of the OFF input. $\boldsymbol{F}, \mathbf{G}$, Average light-evoked conductances from OFF midget $(n=4)$ and OFF parasol ganglion cells $(n=4)$ in control conditions or after $0.1 \mu \mathrm{M} \mathrm{ACET}$ application. Average excitatory (AMPA, NMDA) and inhibitory conductances (Inhib) are shown separately (see Materials and Methods). OFF midget ganglion cells receive a prominent NMDAmediated input, whereas OFF parasol ganglion cells could be adequately fit with a linear I-V relation. $\boldsymbol{H}, \boldsymbol{I}$, Summary of peak conductances in OFF midget $(\boldsymbol{H})$ and OFF parasol $(\boldsymbol{I})$ cells in control (Con, black symbols) or ACET (red symbols). The peak AMPA and NMDA conductance was measured during presentation of a dark spot (at time points indicated by black circle and black diamond symbols in $\boldsymbol{F}$ and $\boldsymbol{G}$, respectively). The inhibitory conductance was measured at the termination of the dark spot (at time point indicated by black triangles in $\boldsymbol{F}$ and $\boldsymbol{G}$ ).

evoked by presentation of the dark spot (OFF response, Fig. 4F$I$ ). In both cell types, the inhibitory conductances occurring at the termination of the dark spot, which were presumably driven by crossover inhibition from the ON-pathway (Crook et al., 


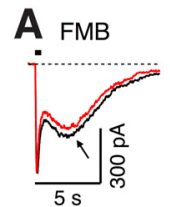

B

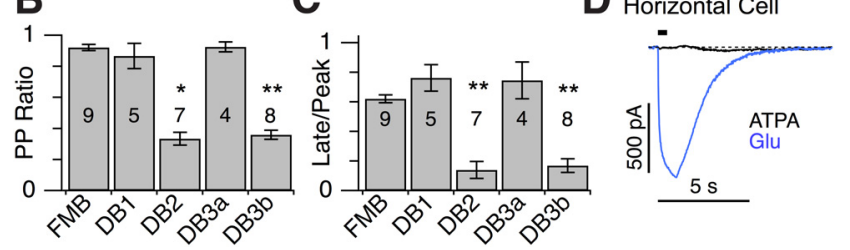

Figure 5. Diverse effects of the KAR agonist, ATPA, across OFF cone bipolar cell types. A, Current responses of OFF cone bipolar cells to paired-puff application of the KAR agonist, ATPA $(0.5 \mathrm{~s}, 10 \mu \mathrm{M}, 15 \mathrm{~s}$ interval). The first response is shown in black, the second response in red. Arrows indicate rebound inward currents. B, Paired puff (PP) ratio (peak amp second response/ peak amp first response) for each bipolar cell type. Error bars indicate \pm 1 SEM. ${ }^{*} p<0.01$, significantly different from FMB (Wilcoxon Rank Sum test). ${ }^{* *} p<0.001$, significantly different from FMB (Wilcoxon Rank Sum test). Note the response desensitization in DB2 and DB3b cells. C, Ratio of current measured at the end of the $0.5 \mathrm{~s}$ ATPA application (Late) over peak evoked current. DB2 and DB3b cells showed more transient response kinetics. D, Puff application of ATPA $(0.5 \mathrm{~s}, 10 \mu \mathrm{m})$ to a horizontal cell did not evoke an inward current, whereas application of glutamate $(0.5 \mathrm{~mm}, 20 \mathrm{~ms})$ to the same cell produced a large inward current. Similar results were obtained in four horizontal cells. $A, D$, Timing of agonist application is indicated by black horizontal bars above traces.

2011), were unaffected by ACET (Fig. $4 F-I$ ). These results, together with the results from the bipolar cell recordings, indicate that KARs in the outer plexiform layer (OPL) convey most, if not all of the excitatory drive to OFF-midget and OFF-parasol ganglion cells.

\section{OFF-bipolar types display functional heterogeneity in KAR expression}

The results from our electrophysiological recordings (Fig. 1) suggest that OFF-bipolar types display functional heterogeneity in KARs, as has been observed in ground squirrel retina (DeVries, 2000; Lindstrom et al., 2014). To further examine these functional differences, we used the KAR agonist, ATPA (Hoo et al., 1999; DeVries, 2000; Paternain et al., 2000), which in heterologous expression systems produces desensitizing currents in GluK1/5 and GluK1/2 and nondesensitizing currents in GluK2/5 heteromers (Paternain et al., 2000). In the retina, we found that paired-puff application of $10 \mu \mathrm{M}$ ATPA, with a $15 \mathrm{~s}$ interval, elicited sustained inward currents in FMB, DB1, and DB3a cells for both the first and second puff (Fig. $5 A-C)$. By contrast, responses in DB2 and DB3b cells were relatively transient and remained strongly desensitized when the second puff was applied $15 \mathrm{~s}$ later (Fig. $5 A-C$ ). We also noted prominent rebound inward currents when the agonist concentration began to decline at the termination of the pressure pulse in FMB, DB1, and DB3a but not in DB2 and DB3b cells (Fig. 5A, arrows). ATPA did not evoke currents in horizontal cells (Fig. 5D), thus confirming the selectivity of ATPA for KARs, over AMPARs. The rebound currents are discussed further below (see Fig. 7).

\section{OFF-bipolar types show heterogeneity in}

GluK1 immunoreactivity

To study the expression of glutamate receptor expression in OFFbipolar types, we performed double immunolabeling using antibodies against the KAR subunit GluK1, together with markers for
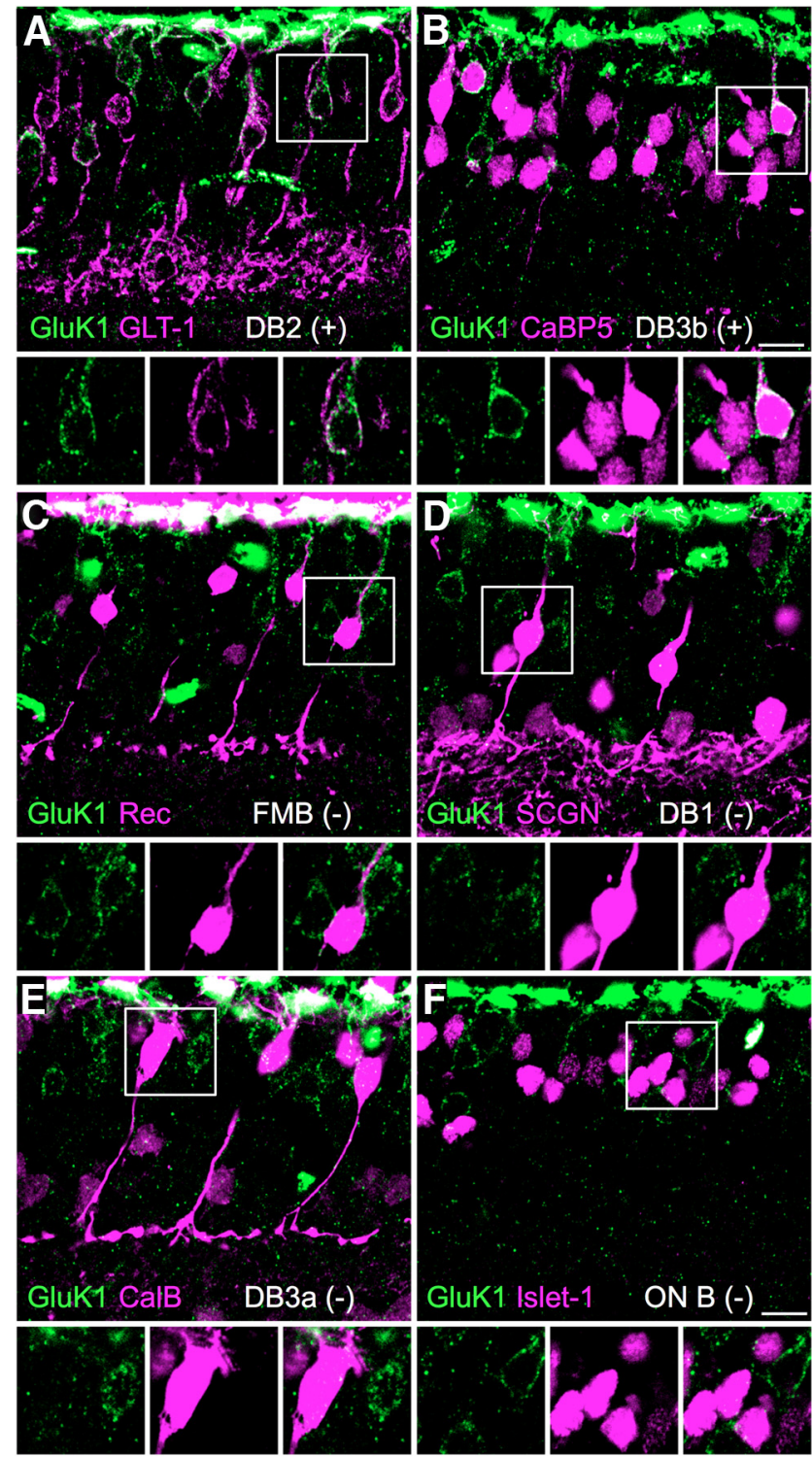

Figure 6. GluK1 expression in OFF-bipolar cells. Confocal projections showing vertical sections of macaque retina double labeled for the KAR subunit GluK1 (green) and bipolar cell markers (magenta). $\boldsymbol{A}$, GluK1 immunoreactivity in DB2 cells, which form a subpopulation of the GLT-1-labeled bipolar cells. B, GluK1 immunoreactivity in DB3b cells, which form a subpopulation of the CaBP5-labeled bipolar cells. DB3a cells and two 0N-bipolar cell types are CaBP5positive but are shown to be negative for GluK1 in $\boldsymbol{E}$ and $\boldsymbol{F}$. $\boldsymbol{C}-\boldsymbol{F}$, GluK1 immunoreactivity is absent from recoverin (Rec)-immunoreactive FMB cells (C), secretagogin (SCGN)immunoreactive DB1 cells $(\boldsymbol{D})$, calbindin (Ca|B)-immunoreactive DB3a cells $(\boldsymbol{E})$, and ON-bipolar cells, all of which are islet-1-immunoreactive (ON B) $(\boldsymbol{F})$. The square regions of interest are shown enlarged in the bottom. Scale bar, $10 \mu \mathrm{m}$.

different cone bipolar cell types (Fig. 6). As has been shown previously (Haverkamp et al., 2001b), GluK1 immunoreactivity is localized in the outer plexiform layer underneath cone pedicles (Fig. 7E). Because some of the bipolar cell markers also label cone pedicles, which are in close proximity to the dendritic tips of the labeled bipolar cells, it was not possible to unambiguously determine whether GluK1 receptor expression colocalized with the bipolar cell dendritic tips in the OPL. However, we noticed that weak labeling of extrasynaptic GluK1 receptors could be detected on the somas of some bipolar cells; we therefore compared expression of this somatic label with the cell markers. To visualize the relatively weak somatic staining, the intense GluK1 immuno- 
$\mathbf{A}_{\mathrm{FMB}}$

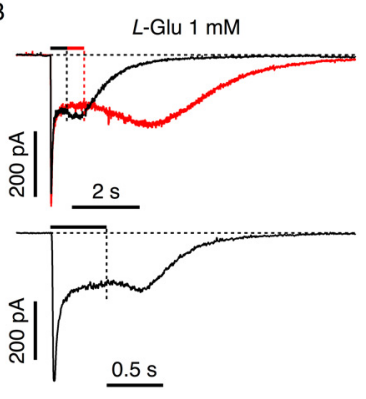

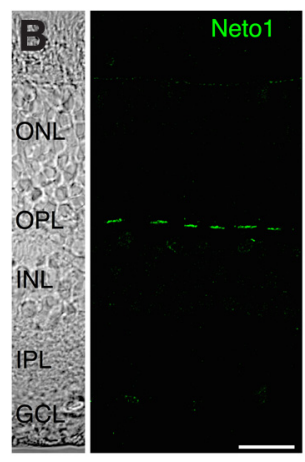

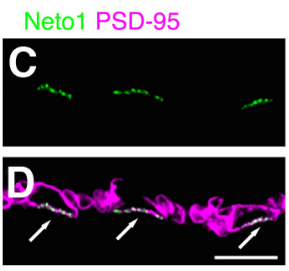

SR-SIM Neto1 SCGN
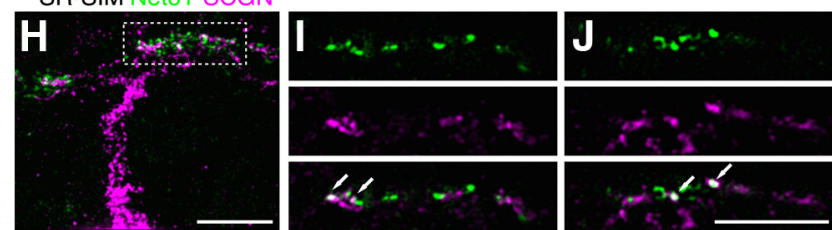

Figure 7. Synaptic localization of Net01 in macaque outer retina. $\boldsymbol{A}$, Examples of rebound currents in two FMB cells in response to application of $1 \mathrm{~mm}$ glutamate. Timing of agonist application is indicated by bars above traces. Note the increase in inward current after the offset of the drug in each case. $\boldsymbol{B}$, Confocal projection showing a vertical section of macaque retina labeled for Net01 (green). Note that Net01 expression is confined to clusters in the OPL and is absent from the IPL. Left, Transmitted light view of the same retinal section with retinal layers indicated. $0 N L$, Outer nuclear layer; $G C L$, ganglion cell layer. C, D, Confocal micrograph of macaque outer plexiform layer labeled for Neto1 (green) and the photoreceptor marker, PSD-95 (magneta), which outlines the rod and cone terminals. Net01 is clustered at the base of cone pedicles (indicated by arrows). $\boldsymbol{E}-\boldsymbol{G}$, SR-SIM images showing single optical sections of different cone pedicles labeled for Net01 (green) and GluK1 (magenta). Bottom, Merged images. Note the lack of overlap between the GluK1 puncta and Net01 puncta. $\boldsymbol{H}$, Projected SR-SIM z-stack showing the primary dendrite and branches of a DB1 cell, labeled with SCGN (magenta), and Net01 staining (green). Dotted rectangle represents the location of the dendritic tips at the base of a cone pedicle in the OPL. $I, J$, Single optical sections through different focal planes of the cone pedicle outlined in H. Bottom, Merged images. Note colocalization of some Net01 puncta with DB1 dendrites (arrows). Scale bars: $\boldsymbol{B}, 10 \mu \mathrm{m} ; \boldsymbol{C}-\boldsymbol{J}, 5 \mu \mathrm{m}$.

fluorescence in the outer plexiform layer is necessarily overexposed in Figure 6, compared with the images shown in Figure 7. Double labeling with antibodies against GLT-1, a marker of DB2 and FMB cells (Grünert et al., 1994; Jacoby et al., 2000), revealed a subpopulation of bipolar cells that were GluK1-positive (Fig. $6 A)$. The double-labeled cells were identified as DB2 cells because GluK1 immunoreactivity is absent in FMB cells (Fig. 6C; FMB identified with antibodies against recoverin) (Milam et al., 1993). Double labeling experiments with antibodies against CaBP5, a marker for DB3a, DB3b, and two ON type bipolar cells (DB4 and rod bipolar cells) (Haverkamp et al., 2003; Puthussery et al., 2013) revealed a subpopulation of cells that were also GluK1positive (Fig. 6B). We conclude that these were DB3b cells because GluK1 immunoreactivity was absent from DB3a cells (Fig. 6E; labeled with calbindin) (Grünert et al., 1994; Puthussery et al., 2013), and all ON cone bipolar cells (Fig. 6F; labeled with antibodies against Islet-1) (Haverkamp et al., 2003). Finally, we found that DB1 cells, which were labeled with antibodies to secre- tagogin (SCGN) (Puthussery et al., 2011), lacked GluK1 immunoreactivity (Fig. 6D). In summary, our results suggest that DB2 and DB3b cells express GluK1 and have desensitizing responses to ATPA (Fig. 5). The absence of the GluK1 subunit in FMB, DB1, and DB3a cells suggests that these cells express GluK2 or GluK3 as their low-affinity subunit.

\section{NETO proteins contribute to functional heterogeneity of retinal KARs}

As noted above, an unusual feature of ATPA-evoked currents in FMB, DB1, and DB3a cells was the appearance of rebound tail currents upon cessation of agonist application (Fig. 5A). Similar tail currents have been attributed to heteromeric KARs in expression systems containing both low-affinity (GluK1-3) and highaffinity (GluK4-5) subunits (Mott et al., 2010; Fisher and Mott, 2011), and are markedly enhanced by coexpression of the KAR auxillary protein, Netol (Fisher and Mott, 2013). In addition, KAR heteromers that contain the GluK4/5 subunits, together with Neto1, show larger rebound currents with increasing agonist concentration (Fisher and Mott, 2013). Thus, we looked for a concentration-dependent effect of glutamate on the magnitude of the rebound currents. Although $0.5 \mathrm{~mm} \mathrm{L-glutamate}$ did not produce obvious tail currents in FMB, DB1, or DB3a cells (Fig. $1 A$ ), increasing glutamate concentration to $1 \mathrm{mM}$ resulted in clear rebound currents in these cell types (Fig. 7A). Example recordings from two FMB cells using different puff durations show that the rebound tail current commenced at the end of the pressure pulse, when the L-glutamate concentration began to decrease (Fig. 7A). In this context, it is noteworthy that FMB, DB1, and DB3a cells exhibited prominent steady-state currents in response to ATPA or glutamate (Figs. $1 A$ and $5 A$ ).

Next, we used immunohistochemistry to determine whether Netol is expressed in the macaque outer retina. We observed punctate immunolabeling for Netol that was confined to the outer plexiform layer (Fig. $7 B$ ). Double labeling with antibodies to PSD-95 showed that Neto1 immunoreactivity is localized at the base of cone pedicles (Fig. $7 C, D$ ), the site where OFF cone bipolar cells contact cones. We sought to determine the following: (1) which low-affinity KAR subunits (GluK1-3) were associated with Neto1; and (2) whether Netol expression was associated with bipolar cells that showed sustained, nondesensitizing responses to glutamate or ATPA application (FMB, DB1, or DB3a cells). We used super-resolution structured illumination microscopy (SR-SIM), which allows localization of these synaptic proteins with a spatial resolution of $\sim 100 \mathrm{~nm}$. Analysis of 23 cone pedicles from three animals indicated that colocalization between Neto1 and GluK1 immunoreactive puncta was low (Fig. 7E-G; $9.3 \pm 2.1 \%$ of Neto 1 puncta were colocalized with GluK1, see Materials and Methods), suggesting that Netol is not associated with the GluK1 subunit and thus is not expressed by DB2 and DB3b cells, which do express the GluK1 subunit (Fig. 6). As outlined above, we assume that FMB, DB1, and DB3a cells express the GluK2 and/or the GluK3 subunits, and thus conclude that the majority of Neto 1 puncta are associated with the GluK2/3 subunits at the dendrites of FMB, DB1, and DB3a cells. We could not show this directly because both antibodies (Neto1 and GluK2/3) were raised in the same species. However, double labeling with antibodies for SCGN (a marker for DB1 cells) (Puthussery et al., 2013) showed Neto1 localization at the dendritic tips of DB1 cells (Fig. $7 \mathrm{H}-\mathrm{J}$ ). It is important to note that Netol puncta were not exclusively localized on DB1 dendrites, suggesting that Neto1 also associates with KARs on FMB and DB3a dendrites. These immunolabeling results, together with our functional data, sug- 
gest that Neto1 is associated primarily with GluK2 or GluK3 receptors in OFFbipolar cells that exhibit relatively sustained responses to agonist application (FMB, DB1, DB3a). Moreover, the presence of rebound tail currents in these cell types indicates that GluK2/3 subunits are likely coexpressed with high-affinity KAR subunits (see Discussion).

\section{Discussion}

We have demonstrated that the OFF cone bipolar cell types that feed into the major sustained and transient ganglion cell types in macaque retina (midget and parasol cells) receive glutamatergic input through KARs. Our immunohistochemical, pharmacological, and electrophysiological evidence further demonstrates that different OFF-bipolar cell types show heterogeneity in their KAR expression (for summary, see Fig. 8). Given the different response properties during glutamate application, we propose that, in primate retina, KAR heterogeneity may contribute to the temporal tuning properties of OFF-bipolar cells, and hence also ganglion cells, as discussed below. The results indicate that AMPA receptors are not required to support transient signaling in the macaque OFF transient (parasol) pathway.

\section{Role of KAR heterogeneity in temporal tuning}

The relatively sustained responses of FMB cells during prolonged agonist application seem appropriate to support signaling to midget ganglion cells at low temporal frequencies. In contrast, sustained agonist application produced relatively transient KAR-mediated responses in DB2 and DB3b cells, indicating stronger desensitization, which will tend to attenuate low temporal frequency signals. Cell-type-specific expression of AMPARs and KARs in OFF-bipolar cells of ground squirrel have led to the proposal that different rates of recovery from desensitization might contribute to diverse temporal tuning in OFFbipolar cells (DeVries, 2000; DeVries et al., 2006). Our results indicate that, at least for OFF parasol ganglion cells, transient signaling can be supported in the absence of AMPARmediated input to OFF-bipolar cells. Overall, diverse KARs, displaying differences in the magnitude and kinetics of desensitization, might contribute to temporal tuning in the various primate OFF-bipolar cells. Further experiments will be necessary to examine this possibility.

\section{Subunit composition of KARs in macaque OFF-bipolar cells}

Our immunohistochemical results indicate that DB2 and DB3b cells express GluK1 as their low-affinity subunit, whereas FMB, DB1, and DB3a likely express GluK2 and/or 3. In accord with these results, ATPA-activated currents in DB2 and DB3b cells were relatively transient and showed longlasting desensitization, similar to GluK1-mediated currents in dorsal root ganglion neurons and a heterologous expression system (Paternain et al., 2000; Wilding and Huettner, 2001; Kerchner et al., 2002). In contrast, ATPA currents in FMB, DB1, and DB3a cells were slower to desensitize, similar to heterologously expressed GluK2/5 (Paternain et al., 2000), and faster to recover, similar to cultured hippocampal neurons (Wilding and Huettner, 2001).

In addition to differences in low-affinity subunits, the presence of high-affinity subunits or auxiliary proteins can contribute further to KAR diversity. We observed rebound inward tail currents at the offset of agonist application in FMB, DB1, and DB3a cells. Previous studies indicate that such tail currents arise from heteromeric combinations of low- and high-affinity subunits and can be explained by a model in which the high-affinity subunit mediates channel opening whereas the low-affinity subunit mediates desensitization. As agonist concentration falls at the end of a pressure pulse, rapid unbinding from the low-affinity subunit relieves desensitization, allowing channels to reopen due to continued occupation of the high-affinity binding site (Mott et al., 2010; Fisher and Mott, 2011, 2013). The rebound tail currents observed in FMB, DB1, and DB3a cells point to expression of heteromeric receptors containing high-affinity subunits. Although rebound currents have been observed in expression systems, they have not, to our knowledge, been demonstrated previously in native KARs. It will be interesting to determine the identity of the putative high-affinity subunits and whether such rebound currents can contribute to physiological responses of primate OFF-bipolar cells.

We have shown that the KAR auxillary protein, Neto1, is clustered at the base of cone pedicles, as has been shown in mouse and ground squirrel retina (Chow et al., 2004; Lindstrom et al., 2014). However, in contrast to the ground squirrel, Neto1 puncta in macaque were largely segregated from GluK1 puncta, and thus were presumably localized to bipolar cells containing GluK2 or 3 as their low-affinity subunit. Consistent with this idea, DB1 dendrites express Netol puncta (Fig. 7) and lack GluK1 subunits. The 
modulatory effects of Netol depend on KAR subunit composition (Copits et al., 2011; Straub et al., 2011; Tomita and Castillo, 2012; Fisher and Mott, 2013). For example, Netol cotransfection markedly increased the magnitude of rebound tail currents in GluK1/5, GluK2/5, GluK3/5, or GluK2/4 heteromers (Fisher and Mott, 2013) and produced a rightward shift in the concentration dependence of desensitization. Straub et al. (2011) showed that coexpression of Neto 1 with GluK2/5 slowed the rate of deactivation and desensitization but accelerated recovery from desensitization, resulting in larger steady-state currents during prolonged agonist application. The presence of Neto 1 in GluK2/3 expressing FMB, DB1, and DB3a cells might reduce KAR desensitization, thereby allowing these cells to produce sustained responses, and expanding the temporal operating range to lower frequencies. For the FMB cells, stronger responses at low frequencies are consistent with the physiological properties of their postsynaptic targets, the midget ganglion cells. In summary, our results suggest that temporal tuning in the primate OFF pathway may depend on selective expression of KAR subunits, as well as KAR accessory proteins.

\section{AMPA receptors in primate OFF-bipolar cells}

Immunohistochemical studies in macaque retina found that GluA1 receptors are expressed at a small minority of OFFbipolar basal contacts with cone pedicles; however, the OFFbipolar types were not determined (Haverkamp et al., 2001a). In marmoset outer retina, GluA1 but not GluK1 puncta were assigned to FMB cells (Puller et al., 2007). These immunohistochemical findings are in contrast to the current electrophysiological results, which demonstrate little functional contribution of AMPA receptors in macaque OFF-bipolar cells. Two previously postulated explanations for the sparse GluA1 receptor expression in macaque OPL (Haverkamp et al., 2001a) remain as possibilities: either there is a single AMPAR dominated OFF-bipolar type or all OFF-bipolar cells express both KARs and very low levels of AMPARs. Because we have sampled the five known macaque bipolar cell types, the former explanation would imply the existence of a rare, AMPAR-driven cell type that was missed in this and previous surveys (Boycott and Wässle, 1991; Haverkamp et al., 2003; Puthussery et al., 2013). The second possibility is that any functional AMPA receptors are distributed across all bipolar cell types at very low density. Mixed AMPA/KAR expressing bipolar cells have been identified in mouse, ground squirrel, and rabbit retinas (Buldyrev et al., 2012; Light et al., 2012; Puller et al., 2013; Lindstrom et al., 2014), where the contribution of AMPARs was substantial in some cell types $(\sim 20 \%)$, in contrast to our current findings. A third possibility is that the GluA1 receptors that have been observed with immunohistochemistry represent AMPARs that could become functional during activity-dependent constitutive cycling (Xia et al., 2006, 2007; Jones et al., 2012), or insertion to synaptic loci (Passafaro et al., 2001), during as yet, unspecified physiological conditions.

It is interesting to note differences in the expression patterns of glutamate receptors in OFF-bipolar cells across vertebrate species. OFF-bipolar cells in salamander are driven primarily through AMPARs (Maple et al., 1999; Cadetti et al., 2005). In nonprimate mammals, GluK2/3 expression is only rarely found in bipolar cells (e.g., mouse and ground squirrel) (Puller et al., 2013; Lindstrom et al., 2014), whereas in primates, robust GluK2/3 expression is found in OFF-bipolar cell dendritic tips (Haverkamp et al., 2001b; Puller et al., 2007). As mentioned above, Netol proteins may combine with different KAR subunits across species. These comparative data indicate that caution is warranted in predicting cross-order homology, and suggest that different species might well use diverse signaling strategies to generate similar functional properties.

\section{KAR antagonists as selective blockers of the primate OFF pathway}

We found that the KAR antagonist, ACET, abolished spiking in OFF-midget and OFF-parasol ganglion cells but had no effect on spiking in ON-type ganglion cells. It is likely that the effects of ACET were restricted to OFF-bipolar cell dendrites because GluK1-3 subunits are absent from bipolar-toganglion cell synapses in the IPL (Grünert et al., 2002), and prior physiological studies implicate AMPA and NMDA receptors at these synapses (Jacoby and Wu, 2001; Buldyrev et al., 2012). Thus, KAR antagonists might be used to selectively suppress the primate OFF pathway at the level of the OPL, similar to L-AP4 for the ON pathway (Slaughter and Miller, 1981, 1985). KAR antagonists could thus be valuable for determining how ON- and OFF-pathway driven inputs combine to generate the response properties of primate retinal ganglion cells, and also offer a pharmacological tool for examining the upstream effects of ON/OFF pathway interactions at higher visual centers.

Note added in proof. After this manuscript had been accepted, Bourghuis et al. (2014) published similar findings in mouse retina.

\section{References}

Abbott CJ, Percival KA, Martin PR, Grünert U (2012) Amacrine and bipolar inputs to midget and parasol ganglion cells in marmoset retina. Vis Neurosci 29:157-168. CrossRef Medline

Blanco R, de la Villa P (1999) Ionotropic glutamate receptors in isolated horizontal cells of the rabbit retina. Eur J Neurosci 11:867-873. CrossRef Medline

Bleakman D, Ballyk BA, Schoepp DD, Palmer AJ, Bath CP, Sharpe EF, Woolley ML, Bufton HR, Kamboj RK, Tarnawa I, Lodge D (1996) Activity of 2,3-benzodiazepines at native rat and recombinant human glutamate receptors in vitro: stereospecificity and selectivity profiles. Neuropharmacology 35:1689-1702. CrossRef Medline

Borghuis BG, Looger LL, Tomita S, Demb JB (2014) Kainate receptors signaling in both transient and sustained OFF bipolar cell pathways in mouse retina. J Neurosci 34:6128-6139. CrossRef Medline

Boycott BB, Wässle H (1991) Morphological classification of bipolar cells of the primate retina. Eur J Neurosci 3:1069-1088. CrossRef Medline

Buldyrev I, Puthussery T, Taylor WR (2012) Synaptic pathways that shape the excitatory drive in an OFF retinal ganglion cell. J Neurophysiol 107: 1795-1807. CrossRef Medline

Cadetti L, Tranchina D, Thoreson WB (2005) A comparison of release kinetics and glutamate receptor properties in shaping rod-cone differences in EPSC kinetics in the salamander retina. J Physiol 569:773-788. CrossRef Medline

Calkins DJ, Sterling P (2007) Microcircuitry for two types of achromatic ganglion cell in primate fovea. J Neurosci 27:2646-2653. CrossRef Medline

Calkins DJ, Schein SJ, Tsukamoto Y, Sterling P (1994) M and L cones in macaque fovea connect to midget ganglion cells by different numbers of excitatory synapses. Nature 371:70-72. CrossRef Medline

Chow RL, Volgyi B, Szilard RK, Ng D, McKerlie C, Bloomfield SA, Birch DG, McInnes RR (2004) Control of late off-center cone bipolar cell differentiation and visual signaling by the homeobox gene Vsx1. Proc Natl Acad Sci U S A 101:1754-1759. CrossRef Medline

Copits BA, Swanson GT (2012) Dancing partners at the synapse: auxiliary subunits that shape kainate receptor function. Nat Rev Neurosci 13:675686. CrossRef Medline

Copits BA, Robbins JS, Frausto S, Swanson GT (2011) Synaptic targeting and functional modulation of GluK1 kainate receptors by the auxiliary 
neuropilin and tolloid-like (NETO) proteins. J Neurosci 31:7334-7340. CrossRef Medline

Crook JD, Peterson BB, Packer OS, Robinson FR, Troy JB, Dacey DM (2008) Y-cell receptive field and collicular projection of parasol ganglion cells in macaque monkey retina. J Neurosci 28:11277-11291. CrossRef Medline

Crook JD, Manookin MB, Packer OS, Dacey DM (2011) Horizontal cell feedback without cone type-selective inhibition mediates "red-green" color opponency in midget ganglion cells of the primate retina. J Neurosci 31:1762-1772. CrossRef Medline

Dargan SL, Clarke VR, Alushin GM, Sherwood JL, Nisticò R, Bortolotto ZA, Ogden AM, Bleakman D, Doherty AJ, Lodge D, Mayer ML, Fitzjohn SM, Jane DE, Collingridge GL (2009) ACET is a highly potent and specific kainate receptor antagonist: characterisation and effects on hippocampal mossy fibre function. Neuropharmacology 56:121-130. CrossRef Medline

De Monasterio FM, Gouras P (1975) Functional properties of ganglion cells of the rhesus monkey retina. J Physiol 251:167-195. Medline

DeVries SH (2000) Bipolar cells use kainate and AMPA receptors to filter visual information into separate channels. Neuron 28:847-856. CrossRef Medline

DeVries SH, Schwartz EA (1999) Kainate receptors mediate synaptic transmission between cones and "Off" bipolar cells in a mammalian retina. Nature 397:157-160. CrossRef Medline

DeVries SH, Li W, Saszik S (2006) Parallel processing in two transmitter microenvironments at the cone photoreceptor synapse. Neuron 50:735748. CrossRef Medline

Diamond JS (2011) Calcium-permeable AMPA receptors in the retina. Front Mol Neurosci 4:27. CrossRef Medline

Dolman NP, More JC, Alt A, Knauss JL, Pentikäinen OT, Glasser CR, Bleakman D, Mayer ML, Collingridge GL, Jane DE (2007) Synthesis and pharmacological characterization of N3-substituted willardiine derivatives: role of the substituent at the 5-position of the uracil ring in the development of highly potent and selective GLUK5 kainate receptor antagonists. J Med Chem 50:1558-1570. CrossRef Medline

Fisher JL, Mott DD (2011) Distinct functional roles of subunits within the heteromeric kainate receptor. J Neurosci 31:17113-17122. CrossRef Medline

Fisher JL, Mott DD (2013) Modulation of homomeric and heteromeric kainate receptors by the auxiliary subunit Neto1. J Physiol 591:4711-4724. CrossRef Medline

Grünert U, Martin PR, Wässle H (1994) Immunocytochemical analysis of bipolar cells in the macaque monkey retina. J Comp Neurol 348:607-627. CrossRef Medline

Grünert U, Haverkamp S, Fletcher EL, Wässle H (2002) Synaptic distribution of ionotropic glutamate receptors in the inner plexiform layer of the primate retina. J Comp Neurol 447:138-151. CrossRef Medline

Haverkamp S, Grünert U, Wässle H (2001a) The synaptic architecture of AMPA receptors at the cone pedicle of the primate retina. J Neurosci 21:2488-2500. Medline

Haverkamp S, Grünert U, Wässle H (2001b) Localization of kainate receptors at the cone pedicles of the primate retina. J Comp Neurol 436:471486. CrossRef Medline

Haverkamp S, Haeseleer F, Hendrickson A (2003) A comparison of immunocytochemical markers to identify bipolar cell types in human and monkey retina. Vis Neurosci 20:589-600. CrossRef Medline

Hollmann M, Heinemann S (1994) Cloned glutamate receptors. Annu Rev Neurosci 17:31-108. CrossRef Medline

Hoo K, Legutko B, Rizkalla G, Deverill M, Hawes CR, Ellis GJ, Stensbol TB, Krogsgaard-Larsen P, Skolnick P, Bleakman D (1999) [ $\left.{ }^{3} \mathrm{H}\right]$ ATPA: a high affinity ligand for GluR5 kainate receptors. Neuropharmacology 38: 1811-1817. CrossRef Medline

Jackman SL, Babai N, Chambers JJ, Thoreson WB, Kramer RH (2011) A positive feedback synapse from retinal horizontal cells to cone photoreceptors. PLoS Biol 9:e1001057. CrossRef Medline

Jacoby RA, Wu SM (2001) AMPA-preferring receptors mediate excitatory non-NMDA responses of primate retinal ganglion cells. Vis Neurosci 18:703-710. Medline

Jacoby RA, Wiechmann AF, Amara SG, Leighton BH, Marshak DW (2000) Diffuse bipolar cells provide input to OFF parasol ganglion cells in the macaque retina. J Comp Neurol 416:6-18. CrossRef Medline
Jones RS, Carroll RC, Nawy S (2012) Light-induced plasticity of synaptic AMPA receptor composition in retinal ganglion cells. Neuron 75:467478. CrossRef Medline

Kerchner GA, Wilding TJ, Huettner JE, Zhuo M (2002) Kainate receptor subunits underlying presynaptic regulation of transmitter release in the dorsal horn. J Neurosci 22:8010-8017. Medline

Kolb H, Dekorver L (1991) Midget ganglion cells of the parafovea of the human retina: a study by electron microscopy and serial section reconstructions. J Comp Neurol 303:617-636. CrossRef Medline

Light AC, Zhu Y, Shi J, Saszik S, Lindstrom S, Davidson L, Li X, Chiodo VA, Hauswirth WW, Li W, DeVries SH (2012) Organizational motifs for ground squirrel cone bipolar cells. J Comp Neurol 520:2864-2887. CrossRef Medline

Lindstrom SH, Ryan DG, Shi J, Devries SH (2014) Kainate receptor subunit diversity underlying response diversity in retinal Off bipolar cells. J Physiol 592:1457-1477. CrossRef Medline

Maple BR, Gao F, Wu SM (1999) Glutamate receptors differ in rod- and cone-dominated off-center bipolar cells. Neuroreport 10:3605-3610. CrossRef Medline

Masu M, Iwakabe H, Tagawa Y, Miyoshi T, Yamashita M, Fukuda Y, Sasaki H, Hiroi K, Nakamura Y, Shigemoto R (1995) Specific deficit of the ON response in visual transmission by targeted disruption of the mGluR6 gene. Cell 80:757-765. CrossRef Medline

Milam AH, Dacey DM, Dizhoor AM (1993) Recoverin immunoreactivity in mammalian cone bipolar cells. Vis Neurosci 10:1-12. CrossRef Medline

Mott DD, Rojas A, Fisher JL, Dingledine RJ, Benveniste M (2010) Subunitspecific desensitization of heteromeric kainate receptors. J Physiol 588: 683-700. CrossRef Medline

Nasu-Nishimura Y, Hurtado D, Braud S, Tang TT, Isaac JT, Roche KW (2006) Identification of an endoplasmic reticulum-retention motif in an intracellular loop of the kainate receptor subunit KA2. J Neurosci 26: 7014-7021. CrossRef Medline

Nomura A, Shigemoto R, Nakamura Y, Okamoto N, Mizuno N, Nakanishi S (1994) Developmentally regulated postsynaptic localization of a metabotropic glutamate receptor in rat rod bipolar cells. Cell 77:361-369. CrossRef Medline

Passafaro M, Piëch V, Sheng M (2001) Subunit-specific temporal and spatial patterns of AMPA receptor exocytosis in hippocampal neurons. Nat Neurosci 4:917-926. CrossRef Medline

Paternain AV, Herrera MT, Nieto MA, Lerma J (2000) GluR5 and GluR6 kainate receptor subunits coexist in hippocampal neurons and coassemble to form functional receptors. J Neurosci 20:196-205. Medline

Perrais D, Pinheiro PS, Jane DE, Mulle C (2009) Antagonism of recombinant and native GluK3-containing kainate receptors. Neuropharmacology 56:131-140. CrossRef Medline

Puller C, Haverkamp S, Grünert U (2007) OFF midget bipolar cells in the retina of the marmoset, Callithrix jacchus, express AMPA receptors. J Comp Neurol 502:442-454. CrossRef Medline

Puller C, Ivanova E, Euler T, Haverkamp S, Schubert T (2013) OFF-bipolar cells express distinct types of dendritic glutamate receptors in the mouse retina. Neuroscience 243:136-148. CrossRef Medline

Puthussery T, Gayet-Primo J, Taylor WR, Haverkamp S (2011) Immunohistochemical identification and synaptic inputs to the diffuse bipolar cell type DB1 in macaque retina. J Comp Neurol 519:3640-3656. CrossRef Medline

Puthussery T, Venkataramani S, Gayet-Primo J, Smith RG, Taylor WR (2013) NaV1.1 channels in axon initial segments of bipolar cells augment input to magnocellular visual pathways in the primate retina. J Neurosci 33:16045-16059. CrossRef Medline

Ren Z, Riley NJ, Garcia EP, Sanders JM, Swanson GT, Marshall J (2003) Multiple trafficking signals regulate kainate receptor KA2 subunit surface expression. J Neurosci 23:6608-6616. Medline

Slaughter MM, Miller RF (1981) 2-Amino-4-phosphonobutyric acid: a new pharmacological tool for retina research. Science 211:182-185. CrossRef Medline

Slaughter MM, Miller RF (1983) An excitatory amino acid antagonist blocks cone input to sign-conserving second-order retinal neurons. Science 219: 1230-1232. CrossRef Medline

Slaughter MM, Miller RF (1985) Characterization of an extended glutamate receptor of the on bipolar neuron in the vertebrate retina. J Neurosci 5:224-233. Medline 
Straub C, Hunt DL, Yamasaki M, Kim KS, Watanabe M, Castillo PE, Tomita S (2011) Distinct functions of kainate receptors in the brain are determined by the auxiliary subunit Netol. Nat Neurosci 14:866-873. CrossRef Medline

Tomita S, Castillo PE (2012) Neto1 and Neto2: auxiliary subunits that determine key properties of native kainate receptors. J Physiol 590:22172223. CrossRef Medline

Venkataramani S, Taylor WR (2010) Orientation selectivity in rabbit retinal ganglion cells is mediated by presynaptic inhibition. J Neurosci 30: 15664-15676. CrossRef Medline

Watanabe M, Rodieck RW (1989) Parasol and midget ganglion cells of the primate retina. J Comp Neurol 289:434-454. CrossRef Medline
Wilding TJ, Huettner JE (1995) Differential antagonism of $\alpha$-amino-3hydroxy-5-methyl-4-isoxazolepropionic and kainate-preferring receptors by 2,3-benzodiazepines. Mol Pharmacol 47:582-587. Medline

Wilding TJ, Huettner JE (2001) Functional diversity and developmental changes in rat neuronal kainate receptors. J Physiol 532:411-421. CrossRef Medline

Xia Y, Carroll RC, Nawy S (2006) State-dependent AMPA receptor trafficking in the mammalian retina. J Neurosci 26:5028-5036. CrossRef Medline

Xia Y, Nawy S, Carroll RC (2007) Activity-dependent synaptic plasticity in retinal ganglion cells. J Neurosci 27:12221-12229. CrossRef Medline 